\title{
Investigation of Occupational Accidents Induce Sever Injury in Fars, Iran from 2005 to 2007
}

\author{
Mojtaba Kamalinia ${ }^{1}$, Heidar Mohammadi ${ }^{1 *}$, Majid Habibi Mohrz ${ }^{2}$, Maziyar Arassi ${ }^{1}$, \\ Mohammad Amin Faghih ${ }^{3}$, Mahdieh Mirzajani ${ }^{4}$ \\ ${ }^{1}$ Department of Occupational Health, University of Medical Sciences, Hamadan, Iran \\ ${ }^{2}$ Tehran University of Medical Sciences, Tehran, Iran \\ ${ }^{3}$ Hormozgan University of Medical Sciences, Bandar Abbas, Iran \\ ${ }^{4}$ Islamic Azad University E-Campus, Tehran, Iran \\ Email: *h.mohammadi@umsha.ac.ir
}

Received June 20, 2012; revised July 27, 2012; accepted August 5, 2012

\begin{abstract}
Occupational accidents and incidents are increased in parallel of growth and expansion of industries. Implementation of preventive measures requires detailed analysis of accidents. So, the major goal of this study was analyze data on occupational accidents induced sever injury in Fars province, in the period 2005-2007 in order to use clues that would support political definition of priorities and strategies for prevention. Data were collected from 200 accidents registered in the Fars Labor Organization. Inclusion criteria were having an occupational accident during 2005-2007 and availability of the events records. Analysis was done using SPSS software (version 16.0) and descriptive analysis was used. The majority of injured workers (98\%) were male. Of the accidents, 79\% were occurred in Fars' capital. The most frequent occupational accidents and injuries occurred in private industries (97.5\%). Most commonly affected workers were aged group 21 - 35. Results also shown that, 84\% of workers had low education under diploma level. Workers with experience less than one year (12 months) had more accident (52.5\%) than others. The most frequent occupational accidents occurred in construction activities (construction building). Of the accident, $24.13 \%$ were occurred due to neglect of regulations and lack of supervision. Unsafe act and unsafe condition were causes of $21.68 \%$ accidents. Accidents analysis and assessment could be used to identify component causing accidents and to give recommendations for accident prevention. Some considerations should be regarding for preventive measures which included: implementing and evaluating training program and establishment of OHS system, as well as insurance position.
\end{abstract}

Keywords: Occupational Accident; Fars Province; Construction Activities; Sever Injury; Iran

\section{Introduction}

Despite safety strategies have been implemented in workplace, occupational accidents and incidents are increased in parallel of growth and expansion of industries and their consequences are unacceptable [1]. Occurrence of terrible accidents such as fire in the Gulf of Mexico and fire of Naftshahr oil well in Iran are pointed to the importance of this issue. The most controversial outcomes related to occupational accidents could be included injury and loss of life, disability [2,3], social impacts and productivity lost [4]. In addition, occupational or industrial accidents influence on work force, economics and impose remarkable cost on society. Because lack of appropriate recording and reporting systems in some developing countries and companies, global exact estimation of accidents is difficult and even impossible. Estimates in-

${ }^{*}$ Corresponding author. dicated 350,000 fatal occupational accidents and 264 million non-fatal in 1998 [5] which had increasingly trend in 2003 [6]. It seems that this challenge could be ahugeimpacton some developing countries [7-9]. Accident causations have been widely investigated and documented in the literatures which included to the age and long length of work shifts [10], occupational safety management [11], job factors and organization related factors [2]. Data obtained from the accidents does not automatically prevent the occurrence of events; therefore the application of preventive measures within system safety can prevent accidents from occurring. So the implementation of preventive measures requires detailed analysis of accidents [12]. According to the Iran Social Security Organization statistics, occupational accidents in 2008 were 23,023 cases which caused damage to 22,134 workers and loss of 109,023 workdays. Fars province located in south of Iran and is the third biggest province in Iran. Statistics of ac- 
cidents in 2006 and 2007 in Fars province show the occurred of 1408 and 1361 accident, respectively that lead to the sixth rank in the ranking of the entire Iran provinces [13]. The analytical study of occupational accidents is the initial key for illustrating and evaluating the evolution of the programming in a country; it can then be used toestablish of governmental priorities pertaining to implementation of prevention rules [14]. As mentioned, preventive measures could be applied based on accident analysis. So, the major goal of this study is to analyze data on occupational accidents in Fars province, in the period 2005-2007 in order to use clues that would support political definition of priorities and strategies for prevention.

\section{Research Process}

In the descriptive study, occupational accident is defined as an incident that had been occurred in the course of work which results in fatal occupational injury, or nonfatal occupational injury. The study covers the occupational accidents in the Fars Province during 2005-2007 which covered by Fars Labor Organization. This organization is responsible for the investigation of accidents and records them. It is worth mentioning, in the Labor Organization, accident investigation is done by inspectors. Data were collected from record registered in Labor Organization. Inclusion criteria were having an occupational accident induced sever injury during 2005-2007 and availability of the events records. Those records, which their data were incomplete and inadequate in that period, were excluded from the study. A checklist was designed as data gathering tool that included two parts. The first part consisted of personal characteristics of injured person included age, marital status, job tenure, education level, nationality, insurance status and second part comprised accidents information which was included to accident place, time event, type of accident, cause of accident, injured organ, industrial category. In general, 200 records were selected and data were collected. Fars province is one of five metropolises of Iran, therefore occurred accidents base on geographic zone were categorized to 5 categories which could be included the center, the northern, the southern, the eastern and the western regions. Statistical analysis was done using SPSS software (version 16.0) and descriptive analysis was used.

\section{Results and Discussion}

Table 1 summarizes details of the personal and accidents included in the study. From all subjects, 98\% were male and $2 \%$ were female. As occurred place, $79 \%$ accidents were occurred in Fars' capital. The most frequent occupational Accidents and injuries occurred in private industries (97.5\%). As seen in Table 1, married workers had higher accident than single workers (53.5\%). This table also shows that $97 \%$ of workers had low education level under diploma (84\%).

Based on the results, a few number of women workers were injured compared to the men workers. This could be due to more difficult and dangerous jobs that are done by men and women are occupied in administrative and office works. This finding is in agreement with the results of the other researchers that reported the high accident numbers among men workers [10,15-17]. As results indicated, the most accidents occurred in Fars capital (Shiraz) $79 \%$. The probably reason is that Shiraz is a metropolis, so that having uppermost industries, therefore more workforces migrate to it in order to find relevant job. Married workers in the present study were more vulnerable to occupational accidents than single workers. It perhaps is due to socioeconomics condition, job dissatisfaction and family problems. This finding is in conflict with the result of the other study [15]. The majority of the recorded accidents (85\%) correspond to the workers with diploma and lower education levels. It may be due to high employment rate in this group and Low education level could be effect on learning of training pro-

Table 1. Details of the accidents and injured peoples.

\begin{tabular}{|c|c|c|c|}
\hline \multicolumn{2}{|c|}{ Variable } & \multirow{2}{*}{$\begin{array}{c}\text { Frequency } \\
158\end{array}$} & \multirow{2}{*}{$\begin{array}{c}\% \\
79\end{array}$} \\
\hline \multirow{5}{*}{ Accident place } & Shiraz & & \\
\hline & South & 24 & 12 \\
\hline & North & 3 & 1.5 \\
\hline & East & 4 & 2 \\
\hline & West & 10 & 5 \\
\hline \multirow{2}{*}{ Gender } & Man & 196 & 98 \\
\hline & Woman & 4 & 2 \\
\hline \multirow[b]{2}{*}{ Marital status } & Single & 93 & 46.5 \\
\hline & Married & 107 & 53.5 \\
\hline \multirow{4}{*}{ Education level } & Illiterate & 28 & 14 \\
\hline & Diploma and below & 168 & 84 \\
\hline & Associated diploma & 3 & 1.5 \\
\hline & Bachelor and higher & 1 & 0.5 \\
\hline \multirow{2}{*}{ Ownership } & Governmental & 5 & 2.5 \\
\hline & Private & 195 & 97.5 \\
\hline \multirow{2}{*}{ Insurance } & Social security & 85 & 42.5 \\
\hline & Nothing & 115 & 57.5 \\
\hline \multirow{2}{*}{ Nationality } & Iranian & 174 & 87 \\
\hline & Foreigner & 26 & 13 \\
\hline
\end{tabular}


grams, skill as well as adaptation of the OHS regulations. In the study of Macedo and Silva [14], the high rate of accidents was reported in the Lisbon (capital of Portugal). The workers who operated in private industry consisted of $97.5 \%$ of accident. Similar to the discussed of Unsar and Sut (9) in their study, in some industries appropriate accident recording and reporting systems were not establishment and. Furthermore, the high rate of workers is occupying in the private industry and small enterprises that are not appropriately cover by supervision regulation in Iran. Of accidents, 13\% were happened among foreigner workers (majority Afghani migrants). These workers were majority operated in construction industry and other workplaces that have high health hazardous risk factors [18] and are not under supervision by responsible organization as appropriate.

Table 2 presents injury frequency in workers based on age and job tenure. As Table 2 shows, the most commonly affected workers are aged group 21 - 35 (49.3\%), aged group 36 - 50 (30.5\%), aged group < 20 (13.5\%). This table also shows that workers with experience less than one year (12 months) had more accident (52.5\%) than others. As Table 2 shows, injuries such as fracture and injured soft tissue in this group had high frequency. In addition, injury rate of fracture and injured soft tissues in workers with job tenure less than 12 months ( $<1$ year) and 13 - 120 months (1 - 10 years) were high 45 (51.1\%), 38 (54.3\%), 36 (40.9\%) and 24 (34.3\%), respectively.

As results demonstrated, mean age of workers was 32.35 years, aged group between 21 and 35 had the highest accident frequency (49\%). These findings are supported with the other researches [10,15-17]. It is worth noting that Bakhtiyari et al. (2012) [15] and Macedo and Silva (2005) [16] have pointed out that workers with less experiment had higher accidents. Results shown that the young workers were exposed to risk of fatal accident that could be attributable to low experience or skill, insufficient training program, existence of various risk factors in workplaces, lack of supervision, and lack of appropriate occupational health and safety management system. In the study of Im et al. [16] the majority of accident were happened among with job tenure less than one month that show important role of job experience and training program in the beginning of the work career.

Table 3 demonstrates frequency of injuries in the different body regions of workers in occupational activity. As seen in Table 3, the most frequent occupational accidents occurred in building construction activities (57.5\%) and service industries 16\%, respectively. Also Table 3 shows, the most injured limbs were right hand 25\%, neck and head $24 \%$, and left hand $20.5 \%$, respectively.

Rate of injured body parts in construction industry (57.5\%) was higher than others industries. It may be due to poor conditions of work, using old and new equipment, required heavy physical demand and inherently dangers work site [18]. Furthermore, there are not relevant supervision laws for construction contractors about selection of competence workers that may be effect on workplaces OHS management. In addition, most of the foreigner workers are occupying in the building construction sectors and are not covered by work insurance. Construction industry is one of the workplaces that have high number of accidents and reported in some of the research $[4,10$, $14,16,17]$. Hands and neck/head injuries were the most common in construction industry. One reason is that the most operations in construction industries are manual. Falling objects is one of the most important risk factors that caused injury. It is in agreement with the results of

Table 2. Details of the injured workers based on age and job tenure categorize.

\begin{tabular}{|c|c|c|c|c|c|c|c|c|c|}
\hline \multirow{2}{*}{ Variable } & & & \multicolumn{7}{|c|}{ Type of injury } \\
\hline & & N (\%) & Death & Fracture & Soft tissue injury & Amputate & Burning & Rupture & Total \\
\hline \multirow{5}{*}{ Age (year) } & $<20$ & $27(13.5)$ & 6 & 8 & 11 & 3 & 1 & 3 & 32 \\
\hline & $21-35$ & 98 (49) & 11 & 50 & 35 & 11 & 2 & 4 & 113 \\
\hline & $36-50$ & $62(31)$ & 17 & 26 & 19 & 5 & 0 & 3 & 70 \\
\hline & $51-65$ & $10(5)$ & 3 & 3 & 4 & 1 & 0 & 1 & 12 \\
\hline & $66-80$ & $3(1.5)$ & 0 & 1 & 1 & 0 & 0 & 0 & 2 \\
\hline \multirow{4}{*}{$\begin{array}{l}\text { Job tenure } \\
\text { (month) }\end{array}$} & $<12$ & 105 (52.5) & 18 & 45 & 38 & 13 & 0 & 7 & 122 \\
\hline & $13-120$ & $73(36.5)$ & 12 & 36 & 24 & 7 & 0 & 3 & 84 \\
\hline & $121-240$ & $15(7.5)$ & 4 & 6 & 6 & 0 & 0 & 1 & 17 \\
\hline & $241-360$ & $7(3.5)$ & 3 & 1 & 2 & 0 & 0 & 0 & 6 \\
\hline Total & & 200 & 37 & 88 & 70 & 20 & 3 & 11 & 229 \\
\hline
\end{tabular}


the previous study conducted by the other researcher $[10,18]$.

Table 4 presents the reasons of occupational accidents. As seen, $24.13 \%$ of accidents were occurred due to neglect of regulations and lack of supervision. Unsafe act and unsafe condition were causes of $21.68 \%$ accidents.

As is apparent in the results, 120 (19.7\%) accidents were happened result from distraction and human errors. This could be consistent with the insufficient or lack of the appropriate training, low level education (97\% under diploma and illiterate), and low job tenure (52.5\% less than 1 year experience). These finding are coherent to the other studies [19,20]. In this study, 224 accidents, almost one third of accidents, were occurred due to neglect legal regulations and supervision. Employers and employees may be don't justify about use of the regulation or haven't sufficient knowledge or awareness about them. In addition, voluntary work in some private industries that have unsafe conditions and lack of supervision by local authority could be key factor for this subject.

Figure 1 illustrates distribution of accident basis on the occurrence month and year. Based on the monthly pattern, April/May (Ordibehesht month in Persian) (12.5\%), and February/march (Isfand month in Persian) (10.5\%) had the highest accident frequency. In addition, the highest accidents were observed in middle (11th to 20th days each month) $37.5 \%$ and end days of each month (21st to 31st days) 34\%.

April/May (Ordibehesht month in Persian) (12.5\%), and February/March (Isfand month in Persian) (10.5\%) had the highest accident numbers. In addition, highest accidents were observed in middle (11 to 20 days (37.5\%)) and end days of month (21 to 31 days (34\%)). In Ordibehesht, changing climate and becoming weather of Fars

Table 3. Distribution of limb injury based on industrial type.

\begin{tabular}{|c|c|c|c|c|c|c|c|c|c|c|c|}
\hline \multirow{3}{*}{$\begin{array}{l}\text { Occupational } \\
\text { activity }\end{array}$} & \multicolumn{11}{|c|}{ Injured limb (frequency) } \\
\hline & \multirow{2}{*}{ N (\%) } & \multirow{2}{*}{$\begin{array}{l}\text { Multiple } \\
\text { site }\end{array}$} & \multirow{2}{*}{ Abdomen } & \multirow{2}{*}{$\begin{array}{l}\text { Neck and } \\
\text { head }\end{array}$} & \multirow{2}{*}{ Thorax } & \multirow{2}{*}{ Spinal cord } & \multirow{2}{*}{ Hip } & \multicolumn{2}{|c|}{ Foot } & \multicolumn{2}{|c|}{ Hand } \\
\hline & & & & & & & & Left & Right & Left & Right \\
\hline Construction & 115 (57.5) & 8 & 5 & 31 & 3 & 15 & 3 & 8 & 20 & 22 & 22 \\
\hline Services & $32(16)$ & 2 & 4 & 6 & 0 & 1 & 0 & 5 & 2 & 7 & 11 \\
\hline Nuclear & $8(4)$ & 1 & 0 & 1 & 0 & 0 & 1 & 2 & 0 & 2 & 2 \\
\hline Electrical & $5(2.5)$ & 1 & 0 & 2 & 0 & 0 & 0 & 0 & 1 & 0 & 0 \\
\hline Chemical & $4(2)$ & 0 & 0 & 2 & 0 & 0 & 0 & 0 & 0 & 2 & 0 \\
\hline Food & $11(5.5)$ & 1 & 0 & 2 & 0 & 0 & 0 & 0 & 1 & 1 & 6 \\
\hline Road construction & $3(1.5)$ & 0 & 0 & 0 & 0 & 0 & 0 & 0 & 0 & 1 & 1 \\
\hline Manufacturing & $16(8)$ & 3 & 0 & 1 & 0 & 0 & 0 & 0 & 0 & 6 & 7 \\
\hline Total & $200(100)$ & 16 & 9 & 48 & 3 & 18 & 4 & 16 & 24 & 41 & 50 \\
\hline
\end{tabular}

Table 4. Risk factors associated with occupational accidents.

\begin{tabular}{lcc}
\hline \multicolumn{1}{c}{ Accident cause } & Number & Percent \\
\hline House keeping & 22 & 3.61 \\
Personal protective equipment (PPE) & 52 & 8.54 \\
Distraction and human error & 120 & 19.71 \\
Unsafe act and condition & 132 & 21.68 \\
Material failures & 15 & 2.46 \\
Heed of regulation and lack of supervision & 147 & 24.13 \\
Fall & 41 & 6.73 \\
Manual material handling & 32 & 5.25 \\
Temperature & 2 & 0.33 \\
Machinery & 46 & 7.55 \\
Total & 609 & 100 \\
\hline
\end{tabular}

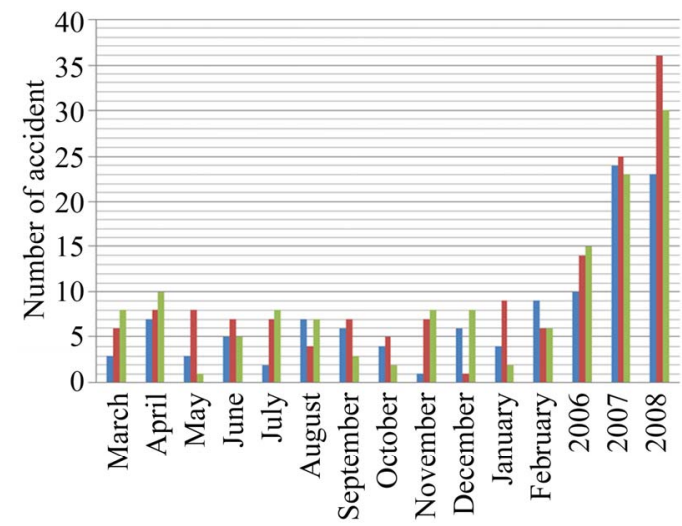

- the first ten days of month

- the second ten days

- the third ten days

Month and year of occurance

Figure 1. Time pattern of occurred accident. 
province toward the heat conditions could be effect on physical and mental work capacities of workers and increasing the risk of accidents. Isfand is the latest month in Iranian year before Nouruz tide and willing of workers for attendance in familiar and friendly aggregations could distraction of workers and lead to the risk or happened of the fatal accidents. With elapse days and up to the month middle, it is likely work pressure increasing and influence on the worker capacity. Liao (2012) [21] shows that the occupational accident in construction industry could be happened based on the seasonal pattern in different seasons.

Data were collected from records that had complete information of accident investigation; therefore many of the incomplete records were excluded in the study. Additionally, respect to the highest workforce in the agricultural sectors, no accident records were founded among reported accident that cause incomplete image of the occupational accident in Fars province.

\section{Conclusion}

As result show, construction industry, men workers, young and inexperienced workers were experienced the accidents that could be result from lack of the OHS system and regulations. Additionally, the accident recording and reporting system is inappropriate and many of the records excluded in the study. Keep in the mind that, implementation of successful occupational health and safety strategies is highly depending to the great extent on the identification of the causes of accidents. Therefore, some considerations should be regarding for prevention measures in Fars province which included: more attention to construction industries, forbidden usage of incompetence foreigner workers, implementing and evaluating training program and establishment of OHS system, as well as insurance position.

\section{REFERENCES}

[1] L. Song, X.-Q. He and C.-W. Li, "Longitudinal Relationship between Economic Development and Occupational Accidents in China,” Accident Analysis \& Prevention, Vol. 43, No. 1, 2011, pp. 82-86. doi:10.1016/j.aap.2010.07.014

[2] V. V. Khanzode, J. Maiti and P. K. Ray, "Occupational Injury and Accident Research: A Comprehensive Review,” Safety Science, Vol. 50, No. 5, 2012, pp. 1355-1367. doi:10.1016/j.ssci.2011.12.015

[3] A. E. Dembe, "The Social Consequences of Occupational Injuries and Illnesses," American Journal of Industrial Medicine, Vol. 40, No. 4, 2001, pp. 403-417. doi:10.1002/ajim.1113

[4] V. S. Santana, J. B. Araújo-Filho, P. R. AlbuquerqueOliveira and A. Barbosa-Branco, "Occupational Accidents: Social Insurance Costs and Work Days Lost,” Re- vista de Saúde Pública, Vol. 40, No. 6, 2006, pp. 1-8.

[5] P. Hämäläinena, J. Takala and K. L. Saarela, "Global Estimates of Occupational Accidents," Safety Science, Vol. 44, No. 2, 2006, pp. 137-156. doi:10.1016/j.ssci.2005.08.017

[6] P. Hämäläinena, J. Takala and K. L. Saarela, “Global Trend According to Estimated Number of Occupational Accidents and Fatal Work-Related Diseases at Region and Country Level,” Journal of Safety Research, Vol. 40, No. 2, 2009, pp. 125-139. doi:10.1016/j.jsr.2008.12.010

[7] M. Pavlic, B. Likar, A. Pavlic and M. Markic, "Managing Occupational Injuries Records in Slovenia from 1948 to 2008," Safety Science, Vol. 49, No. 6, 2011, pp. 834-842. doi:10.1016/j.ssci.2011.01.013

[8] A. Z. Rabi, L. W. Jamous, B. A. Abudhaise and R. H. Alwash, "Fatal Occupational Injuries in Jordan during the Period 1980 through 1993," Safety Science, Vol. 28, No. 3, 1998, pp. 177-187. doi:10.1016/S0925-7535(98)80007-6

[9] S. Unsar and N. Sut, "General Assessment of the Occupational Accidents That Occurred in Turkey between the Years 2000 and 2005," Safety Science, Vol. 47, No. 5, 2009, pp. 614-619. doi:10.1016/j.ssci.2008.08.001

[10] V. Villanueva and A. M. Garcia, "Individual and Occupational Factors Related to Fatal Occupational Injuries: A Case-Control Study," Accident Analysis \& Prevention, Vol. 43, No. 1, 2011, pp. 123-127. doi:10.1016/j.aap.2010.08.001

[11] B. Fernández-Muñiz, J. M. Montes-Peón and C. J. Vázquez-Ordás, "Relation between Occupational Safety Management and Firm Performance,” Safety Science, Vol. 47, No. 7, 2009, pp. 980-991. doi:10.1016/j.ssci.2008.10.022

[12] P. Arocena, I. Núñez and M. Villanueva, “The Impact of Prevention Measures and Organisational Factors on Occupational Injuries,” Safety Science, Vol. 46, No. 9, 2008, pp. 1369-1384. doi:10.1016/j.ssci.2007.09.003

[13] Iran Social Security Organization, "Report of Work Related Accident," 2008.

[14] A. C. Macedo and I. L. Silva, "Analysis of Occupational Accidents in Portugal between 1992 and 2001," Safety Science, Vol. 43, No. 5-6, 2005, pp. 269-286. doi:10.1016/j.ssci.2005.06.004

[15] M. Bakhtiyari, A. Delpisheh, S. M. Riahi, A. Latifi, F. Zayeri and M. Salehi, "Epidemiology of Occupational Accidents among Iranian Insured Workers," Safety Science, Vol. 50, No. 7, 2012, pp. 1480-1484. doi:10.1016/j.ssci.2012.01.015

[16] H.-J. Im, Y.-J. Kwon, S.-G. Kim, Y.-K. Kim, Y.-S. Ju and H.-P. Lee, "The Characteristics of Fatal Occupational Injuries in Korea's Construction Industry, 1997-2004,” Safety Science, Vol. 47, No. 8, 2009, pp. 1159-1162. doi:10.1016/j.ssci.2008.11.008

[17] Y.-H. Lin, C.-Y. Chen and J.-L. Luo, "Gender and Age Distribution of Occupational Fatalities in Taiwan,” Accident Analysis \& Prevention, Vol. 40, No. 4, 2008, pp. 1604-1610. doi:10.1016/j.aap.2008.04.008

[18] B. Y. Jeong, “Occupational Deaths and Injuries in the 
Construction Industry,” Applied Ergonomics, Vol. 29, No. 5, 1998, pp. 355-360. doi:10.1016/S0003-6870(97)00077-X

[19] M. Celik and S. Cebi, "Analytical HFACS for Investigating Human Errors in Shipping Accidents," Accident Analysis \& Prevention, Vol. 41, No. 1, 2009, pp. 66-75. doi:10.1016/j.aap.2008.09.004

[20] G. J. M. Read, M. G. Lenné and S. A. Moss, “Associa- tions between Task, Training and Social Environmental Factors and Error Types Involved in Rail Incidents and Accidents,” Accident Analysis \& Prevention, Vol. 48, 2012, pp. 416-422. doi:10.1016/j.aap.2012.02.014

[21] C.-W. Liao, "Pattern Analysis of Seasonal Variation in Occupational Accidents in the Construction Industry," Procedia Engineering, Vol. 29, 2012, pp. 3240-3244. doi:10.1016/j.proeng.2012.01.473 